\title{
Analysis on Problems and Countermeasures of Public Service of Massive Open Online Courses in China
}

\author{
Yang Fen \\ School of Foreign Languages, Kunming University, Kunming, 650214, China
}

Keywords: flipped classroom; public service; mob education; open education; countermeasures and suggestions

\begin{abstract}
In the past two years, many problems in curriculum construction and platform operation in China's colleges and universities need to be further explored. First of all, colleges and universities in our country have not yet nurture in the inner motivation and open education idea of the formation and development of curriculum education. In order to promote the healthy development of the class, this paper analyzes the problems existing in the public service of our country's lesson education, and analyzes several key problems based on the current situation of the course teaching, and puts forward some countermeasures and suggestions on the public service of the higher education, which has certain reference significance.
\end{abstract}

\section{Introduction}

The English acronym is an abbreviation of English, which can be translated into a large-scale open course. It is a new model of network education. According to the resources of famous school and famous teacher, using computer, Internet and multimedia technology, many well-known institutions all over the world have joined the MOOC platform, and millions of people have been successfully known. The style of the school. The new teaching form has formed a certain impact on the traditional teaching mode, and it also brings some opportunities to the reform of traditional teaching. Therefore, we need to carry out positive innovation and change, study the plan of the teaching of the course in depth, and reform the traditional classroom teaching by drawing lessons from the course of the lesson, and promote the traditional teaching. The harmonious development of Moore education and traditional education.

\section{Analysis on the current situation of MOOCs public education service}

With the continuous development of computer, Internet and multimedia technology, there are many online network education platforms in our country, such as good university online, school online, online open curriculum sharing platform for high level universities in China, shared curriculum and love course network of the eastern and western universities and colleges, and good online and school online. Based on the network teaching platform of Shanghai Jiao Tong University and Tsinghua University, the online open curriculum sharing platform of high level universities in China is co founded by 985 universities and C9 universities. The shared curriculum of the alliance between the East and the west is jointly constructed by 24985 colleges and universities, and the love curriculum network is the educational resource sharing platform introduced by the Ministry of education. Thus, MOOCs teaching mode has raised the upsurge of network teaching. In order to further analyze the problems existing in the public service of the higher education in China's colleges and universities, some of the research projects in Table 1 are taken as an example to analyze the problems. 
Table 1 research project on public service of MOOCs Education

\begin{tabular}{|l|l|c|c|c|c|c|}
\hline & $\begin{array}{l}\text { The } \\
\text { influence } \\
\text { of the } \\
\text { traditional } \\
\text { project } \\
\text { class in the } \\
\text { class }\end{array}$ & $\begin{array}{c}\text { The } \\
\text { problem of } \\
\text { overturning } \\
\text { the } \\
\text { classroom } \\
\text { and the } \\
\text { teaching } \\
\text { model of } \\
\text { MOOCs }\end{array}$ & $\begin{array}{c}\text { The } \\
\text { influence } \\
\text { of } \\
\text { MOOCs on } \\
\text { Higher } \\
\text { Education }\end{array}$ & $\begin{array}{c}\text { The } \\
\text { construction } \\
\text { of the } \\
\text { resource } \\
\text { platform for } \\
\text { MOOCs }\end{array}$ & $\begin{array}{c}\text { The } \\
\text { effect of } \\
\text { learning } \\
\text { MOOCs } \\
\text { and the } \\
\text { credit } \\
\text { problem }\end{array}$ & Other \\
\hline $\begin{array}{l}16 \% \\
\text { Research } \\
\text { ratio }\end{array}$ & $17 \%$ & $20 \%$ & $25 \%$ & $6 \%$ & $16 \%$ \\
\hline Total & \multicolumn{7}{|c|}{$100 \%$} & & \\
\hline
\end{tabular}

As shown in Table 1, this study mainly focuses on the study of the existing problems in the public education service in the five research projects, including the overturned class + MOOCs mixed teaching model, the influence of the Mu lesson on the traditional education and higher education, the construction of the platform resources of the class, and some other aspects. The factors are also studied. Through the analysis of these problems, we can get some key problems in the course of the implementation of the lesson, and then we can put forward the countermeasures and suggestions for the development of the public service of the class education.

\section{The problems in the public service of 2 MOOCs Education}

The emergence of the class has greatly promoted the sharing of teaching resources. As a new thing of traditional education, it has been gradually accepted by the public, and it has also raised a large-scale upsurge of learning lessons. But there are many problems behind it. Only to solve these difficulties and challenges can we make the lesson better serve us.

\subsection{Educational Technology.}

It is a perfect combination of education and network technology, which facilitates the convenience of education to a certain extent, but it is not mature in its own technology, especially for higher education. For example, the supervision of students, this seemingly very small problem, but from the present technical level is still a problem that can not be solved, even the real-time monitoring of the students, can not enhance the integrity of their learning and self-discipline. In order to improve students' subjective awareness and initiative, we need to start with educational technology and improve students' interest in learning.

\subsection{The challenge of teaching model.}

MOOCs changed the traditional teaching mode and changed the traditional lecture into lectures and interactive evaluation.

In the form of flipped classroom, the traditional dull and passive classroom is transformed into the basis of individual self-study. This teaching model seems to lead to the classroom atmosphere, but influenced by the profound influence of traditional education, whether the students' self-study ability can adapt to the needs of the flipped class is a very important question. The content of the class is given to the students to digest independently. Most people worry whether the students can truly digest the knowledge and learn the learning model. Whether it can really get students' approval is a problem that public education needs to face.

\subsection{The issue of credit accreditation.}

From regular classroom learning resources to students' spontaneous learning resources, and assessment of learning effectiveness.

It is another difficult problem to be faced with. There are two main problems that need to be 
solved. First, whether the standard of credit assessment has reached the quality requirements of the credit award, and then how to verify that the students have completed the above course through a reliable evaluation system; obviously from the school level, the school is from the school. The coordinated behavior can not perfectly solve the problem of credit recognition, which requires the mob itself to solve this problem from the technical level.

\subsection{The problem of educating people.}

MOOCs teaching mode has many problems in training talents compared with the traditional mode. In the traditional classroom, students can interact through three-dimensional space language and body movements. In the course of teaching, the interaction of oral language is often replaced by the written form of expression, which makes the socialization function of the students weaken and the individual's sociality is ignored. It is difficult to meet the needs of the society.

\section{The countermeasures and suggestions on the development of MOOCs education public service}

In order to achieve a reasonable and healthy development of the teaching model of Mu lesson, it is necessary to take the supporting hardware, teaching environment, system and policy as the basis, and combine the actual conditions of our country and the present situation of the education of the lesson.

\subsection{The state and government aspects.}

As for the upsurge of the model, the Department of education should have a thorough understanding of the current situation of the development of the class, and summarize the law of its development so as to strengthen the enthusiasm and autonomy of the college students. We should build a national curriculum development organization, overall plan the overall situation, coordinate the interests of all parties, formulate regulations related to the curriculum, and promote the rational development of the network teaching platform. We should strengthen the opening of educational resources, strengthen the construction of teaching staff, study the construction of the resources of the platform and the standard of quality certification, guide the certification of the Cross School Credit and so on, and improve the teaching effect of the course. The government should also increase the investment of funds, organize the social resources and strength to participate in the construction of the class, encourage and promote the innovation of the colleges and universities, and form a joint effort to develop the operation mechanism.

\subsection{Colleges and Universities.}

Colleges and universities play a very important role in the construction of the curriculum, but there are many problems in the course of development, which also brings great challenges to colleges and universities. As the organizer of education, colleges and universities should attach importance to the development of the class and provide the full range of services for them. Schools should set up special institutions for teaching and teaching, study the law of teaching and development, explore the integration of online learning and flipping classes, and give them some teacher resources, material resources, funds and technology, especially for the teachers who have been taught. The mutual recognition of credits is an important content of network learning. This is an important content of studying the students' learning effect. Colleges and universities should establish the quality and classification system of the class, so that the quality and the level to a certain degree can carry out credit mutual recognition. In order to ensure teachers' teaching incentive policies and make teaching activities smoothly, they can be built.

\subsection{The level of Teachers.}

The development of MOOCs has changed the traditional teaching mode of teachers. In the face of the opportunities and challenges that the class brings, the teachers should take part in the construction of the lesson with open and positive attitude. Through practice and innovation, we 
should conscientiously study the teaching and development rules of the class, adapt to the students' self-study foundation and turn the classroom teaching mode. Tools and technology, so teachers need to strengthen the concept of teamwork and work together with the teachers team to complete teaching tasks and tasks. The teaching process of teachers should be transformed from the main body of the teacher to the student body. By changing the teaching style and teaching skill, the teacher should improve the enthusiasm of the students, change the focus of the teacher's work from knowledge transfer to knowledge creation, actively engage in scientific research, increase the reserve of knowledge, enrich the teaching content, and improve the quality of teaching. Quantity and teaching ability.

\section{Conclusion}

In order to explore the healthy and rational development of the public education service of $\mathrm{Mu}$ lesson, this paper analyzes the problems in the public service of our country's lesson education, including the problems of educational technology, the challenge of teaching mode, the recognition of credit and the training of talents, and the need for further improvement in these aspects. According to the current situation of the development of MOOCs and the comprehensive supporting hardware, teaching environment, system and policy, this paper puts forward some countermeasures and suggestions on the development of the class according to the national conditions of our country, hoping to play a positive role in promoting the development of the lesson.

\section{References}

[1] Li Manli. Characteristics of MOOCS and its instructional design principles [J]. Education research, Tsinghua University, 2013 (4):13-21.

[2] Wu Wanwei. Cold thinking of "MOOCs craze" [J]. Fudan Education Forum, 2014 (1):10-17.

[3] Luo Libin. The background, influence and Countermeasures of promoting higher education by curtain class. [J]. China Electric Power Education, 2014 (36):14-16.

[3] Ma long long, Yuan song he.MOOCs: model innovation and indigenous enlightenment of educational openness [J]. Chinese higher education research, 2014 (12):20-26.

[4] Liu Hehai, Li Qibin. Discussion on the concept of "Chinese MOOC" and platform optimization strategy [J]. Modern educational technology, 2014, (05): 81-87.

[5] Ji Fu Jun, Li Li Chung. Research on the promotion strategy of MOOC development in China [J]. China distance education, 2014, (11): 27-32.

[6] Hu Qin Tai, Lin Xiao Fan. Service oriented MOOCs analysis and instructional design research [J]. Chinese audio-visual education, 2015, (1): 39-43.

[7] Zhu Qingfeng. The dilemma and choice of the development of "MOOCs" in Higher Education in China. [J]. education development research, 2014, (23): 73-77.

[8] Liu Mengchao, Xiao Jirong, Chen Rong. Application of data mining in user behavior analysis. Computer knowledge and technology, 2012, 31 (04): 7409-7412.

[9] Pan Feng Nan. Analysis and Research on user behavior of campus network [J]. Journal of Yangtze University, 2013, 23 (02): 1403-1409

[10] Li Changxian. Research on school users' network behavior classification system [J]. Statistics and management, 2013, 04 (061):144-145.

[11] Duan Jinju, Yu Shengquan, Wu Pengfei. Research perspective and evolution trend of socialized learning-Analysis Based on open knowledge community [J]. Distance education magazine, 2016 (03):66-69.

[12] Li Zhimin. The rise of "MOOCs" has aroused the awakening of Chinese universities [J]. 
Higher education in China, 2014, (7): 30-33.

[13] Yang Yuqin. MOOC learner personalized learning model construction [J]. China Audio-Visual Education, 2014, (6): 6-10.

[14] Xiao Jun, Hu Yiling, Chen Jing Ya, Wu Jie. Research on MOOCs operation mechanism under Open Education [J]. Chinese audio-visual education, 2015, 6(3): 10-14.

[15] Yuan Songhe, Liu election. Current situation and common problems of MOOC practice in Chinese Universities[C]. Rport on Modern Distance Education from the Chinese University MOOC practice report, 2014, (4): 3-12. 